\title{
Interconnecting Theory A and ABC Model of Organizational Research Performance
}

\author{
P. S. Aithal ${ }^{1}$, \& P. M. Suresh Kumar ${ }^{1}$ \\ ${ }^{1}$ Srinivas Institute of Management Studies, Pandeshwar, Mangalore -575 001, India \\ E-mail: psaithal@gmail.com
}

Type of the Paper: Research Paper.

Type of Review: Peer Reviewed.

Indexed in: OpenAIRE.

DOI: http://dx.doi.org/10.5281/zenodo.268598.

Google Scholar Citation: IJMTS

\section{How to Cite this Paper:}

Aithal, P. S., \& Suresh Kumar P. M. (2016). Interconnecting Theory A and ABC Model of Organizational Research Performance. International Journal of Management, Technology and Social Sciences (IJMTS), 1(1), 1-13.

DOI: http://dx.doi.org/10.5281/zenodo.268598.

International Journal of Management, Technology, and Social Sciences (IJMTS)

A Refereed International Journal of Srinivas University, India.

(C) With Authors.

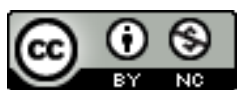

This work is licensed under a Creative Commons Attribution-Non Commercial 4.0 International License subject to proper citation to the publication source of the work.

Disclaimer: The scholarly papers as reviewed and published by the Srinivas Publications (S.P.), India are the views and opinions of their respective authors and are not the views or opinions of the SP. The SP disclaims of any harm or loss caused due to the published content to any party. 


\title{
Interconnecting Theory A and ABC Model of Organizational Research Performance
}

\author{
P. S. Aithal ${ }^{1}$, \& P. M. Suresh Kumar ${ }^{1}$ \\ ${ }^{1}$ Srinivas Institute of Management Studies, Pandeshwar, Mangalore -575 001, India \\ E-mail: psaithal@gmail.com
}

ABSTRACT

The higher education and research institutions have an objective of creating new knowledge continuously using their people as resources and success of the organizations depend on how much new knowledge they have created during a given period of time. A simple measurement system for calculating annual research index of organizations namely ABC model has been developed by Aithal P. S. and Suresh Kumar during 2016. As per this model, the annual research performance can be determined by knowing the research index of the institution/ individuals and is calculated by considering the total number of research publications during that period. Application of the theory of organizational performance namely 'Theory A' can improve research productivity of educational institutions. This is a management strategy which believes in delivering target as responsibility, feeling of creativity and contribution for motivation, identifying with the organization as commitment and accountability as a hallmark of efficiency. In this paper, we have interconnected Theory A of organization performance with $\mathrm{ABC}$ model of research productivity in order to enhance research productivity of the organizations.

Keywords : Enhancement of research productivity, Theory A, ABC model of research productivity.

\section{INTRODUCTION :}

New knowledge creation through research is a continuous process in higher educational institutions due to many reasons which include, identification of new problems to be solved in a given area, creation of new knowledge in a given subject, interconnecting and interrelating different subjects, identifying new skills, ideas, concepts, theories, developing new technologies and systems which makes life more comfortable, finding the relationship between various variables of a system in an effort to simplify it, deepening insight into a system or method with an intention of discovering new things, etc. Being important as an organization in the society, higher educational institutions have two major objects which include enhancing the knowledge, skills, and experience of the aspiring students, and creation of new knowledge in identified/related areas of study. In this regard, the higher education institutions can do innovations in the process of providing quality education to its students by means of setting its objects implementing them effectively by means of various best practices [1-24].Like other organizations which have objective of enhancing their productivity or quality of service for long term benefits, higher education institutions also have to struggle to enhance their output or performance which is mainly creating and disseminating new knowledge through research and publications. This can be achieved by including both faculty members and students actively in research. ABC model of research productivity index takes into account the quantum of research publications during a period of time. The organizational objectives of increasing the research productivity can be effectively realized by adopting the features of organizational performance theory called Theory of Accountability (Theory A).

\section{THEORY 'A' AND ORGANIZATIONAL PERFORMANCE :}

Many theories were developed during last fifty years which accounts the performance of organizations based on human productivity. This includes, Theory X, Theory Y [25], and Theory $\mathrm{Z}$ [26]. As time progress, due to changes in technology, human aspirations, economical \& social conditions, and 
environmental knowledge, these theories became obsolete and irrelevant. Recently developed and published organizational performance theory for $21^{\text {st }}$ century called Theory A (Theory of Accountability) by Aithal P. S. and Suresh Kumar [27] challenges the existing propositions on human behaviour and motivation in organizations by presenting new propositions to enhance organizational productivity. It provides better insights on current organizational perspective during $21^{\text {st }}$ century in competitive environment and changed employee mindset of the modern society which has undergone enormous change due to changes in technology and means of production, production relations, customer and societal perception and ones own expectations. Quest for creativity, propels the employee to contribute to the organization drawing positive energy from his innate potential and tuned to best performance models around him through self-exploration. This is a management strategy which believes in fulfilling its own objectives for enhancement of output by making its people delivering targets as responsibility, feeling of creativity and contribution for motivation, identifying with the organization as commitment and accountability as a hallmark of efficiency. Essential components of Theory of Accountability (Theory A) are : (1) Planning, (2) Target setting, (3) Motivation, (4) Work Strategies, (5) Responsibility, (6) Role model, (7) Monitoring \& Guiding, and (8) Accountability [27-31].

\section{ORGANIZATIONAL RESEARCH PRODUCTIVITY \& ABC MODEL :}

Organizational Research Productivity is an important criterion to judge the organizational research output. Various metric systems are used to measure the organizational research output which include the number of publications for a given observation period. Accordingly one can determine annual research productivity, biannual research productivity, or five years research productivity of a higher educational or research organization. Even though a number of models used to calculate the research productivity have been developed my many researchers based on logical postulates, only peer reviewed journal publications and peer reviewed books/book chapters can be acceptable for calculation of research productivity since they prove acceptable standards. One of such model that uses peer reviewed publications to calculate organizational research index is the recently developed ABC model [32]. According to ABC model of Institutional/individual research productivity, the success of higher education and research institutions - the objectives being creation of new knowledge through research involving all faculty members and students depends on how much new knowledge has been created during a given observation period, say an year. As per the model, the annual research performance can be determined by knowing the research index (R.I.) of the institution or the individuals, calculated by considering the total number of research publications during that period. The institutional research productivity is calculated using a metric which consists of three institutional variables and one parameter. The three variables are identified as (A) Number of Articles published in peer-reviewed journals, (B) Number of Books published, and (C) Number of Case studies and/or Book Chapters published during a given time of observation. The parameter used is a number of full-time Faculty members (F) which remains constant during the given period of observation [32-39]. ABC model for measuring institutional performance [32-39] is based on following postulates. (1) The Quality of higher education depends on the ability of the institution in new knowledge creation. (2) The ability of new knowledge creation of the institution depends on the institutional research and publications by both faculty members and students. (3)The institutional publication is measured by calculating its annual average publications. (4) The institutional publication ability is measured by its annual publications in terms of the number of Articles published in Journals (A), the number of Books published in the subjects/Edited volumes (B), and the number of Business cases and Book chapters (C) published. (5)The Research productivity (P) of the institution can be measured by knowing research index $(\alpha)$ and weighted research index $(\beta)$, which shall be calculated using average publications in Journals, average publications of books and an average number of publications of Business cases. The research index per year $(\alpha)$ is calculated using the formula $\alpha=(2 \mathrm{~A}+5 \mathrm{~B}+\mathrm{C}) / \mathrm{F}$, and the weighted research index $(\beta)$, per year, is calculated using 
the formula $\beta=(2 \mathrm{~A}+5 \mathrm{~B}+\mathrm{C}) / 8 \mathrm{~F}$, where $\mathrm{A}=$ No. of publications in Journals in that year, $\mathrm{B}=$ No. books published in that year, $\mathrm{C}=$ No. of Publications of Business Cases published in that year, and $F=$ No. of full-time Faculty members in that institution during that year. In the above formula, the weightage for a research article A is 2 and that of book B is 5 and the case study is 1 , based on a quantified assumption of the relative significance \& efforts involved in generating it arrived at through a summated scaling technique. (6) The annual research productivity (research index $\alpha$ ) of the organization decides institutional ranking.

\section{THEORY A APPLIED TO RESEARCH ORGANIZATIONS :}

In higher education and research organizations, Theory A plays an important role in all the stages of organizational performance. Adopting Theory A by intensifying all its constructs on organizational dynamic resources (people) enhance research productivity. Organizational director/leader has multi-role in implementing Theory $\mathrm{A}$ in his/her organization effectively. The director, being the role model in an organization, expected to be involved in setting up the goal of individual researcher, planning in their annual research, supports acquiring required resources, building up their responsibility towards hard work through successful working strategy and innovative thinking, be role model for every researcher through their exceptional personal contribution, monitoring each and every researchers performance through conducting meetings and interaction with individual researcher, and by fixing accountability on individuals and groups for better performance as well as poor performance. It is the strategy and the smartness of individual administrator who is appointed as the director of the organization to develop a healthy competitive environment in the organization for enhancing and optimizing organizational research productivity through publications. Thus the effective implementation of Theory A by an administrator who can also be a role model for researchers through his personal contribution can increase organizational research index to be calculated using ABC model.

\section{IMPROVEMENT OF RESEARCH PRODUCTIVITY USING THEORY A :}

The essential components of Theory A applied to any higher education institution are explained as follows :

\section{Planning :}

The vision, mission, and objectives of the organization should be clear on organizational contribution towards research and development. Creation of new knowledge and using it for organizational progress should be a central activity for any organization whether it is production oriented or service oriented. By setting the objectives of the organization as research oriented and research focussed, an organization can encourage its every employee to think innovatively. Based on planning organizational objectives and proper planning to achieve it every organization can recruit and train innovative employees who have the passion for research and documentation so that organization can develop its planning strategy as the blue ocean to become a monopoly in its business. While considering higher education and research institutions, the organizational objectives should be planned towards involving more and more people resources in maximizing the research output by creating new knowledge and publication/patenting. Thus, being the first element of the theory of Accountability, planning finds a very important role in transforming a higher education organization into an active research institution for optimized contribution from employees. The various steps to be followed in planning step are :

(1) Either individually or jointly head of the organization analyse the institutional strength, weaknesses, opportunities and challenges towards fulfilling its objectives of creating new knowledge, ideas, and concepts through researching and sharing it with the society through publication/patenting.

(2) While identifying the problems in transforming the organization into a highly productive organization based on setting up the objectives in favour of research contribution and publications.

(3) The planning process involves identifying and recruiting right resources in all positions of the organization to fuel the research objectives.

(4) Organization should clearly plan its human resource recruitment and training policy by disclosing organizational objectives in favour 
of research contribution of individuals and teams.

(5) Planning should also involve allocation of the financial resource to promote various research centres, research groups, research projects and financial support to various activities related to enhancing organizational research output and publications.

\section{Target Setting :}

This includes setting the research target for the organization, for various divisions, groups, and individuals. Target can set for the entire number of Research centres in the organization, number of projects to be applied for funding, number peer reviewed publications, the number of books to be published, etc. during a given year. The various steps to be followed in Target Setting process are :

(1) Based on the institutional research policy, the minimum target for the organization, departments, groups and every individual should be fixed. This includes the quarterly target, half-yearly target, annual target, and so on. Such target should be communicated to everyone in the organization.

(2) This stimulates a process of mutual consultation and dialogue among members of the organization to plan and achieve the target.

(3) As a result, the members realize their challenge in terms of new knowledge creation and how to redefine their individual and group goal.

(4) The target setting for individuals and groups makes everybody prepare and devote their effort towards better performance.

(5) The target should focus on how the research topics to be explored during the given time frame, research projects to be applied for funding, how many books, research articles, and case studies should be published during a given year.

(6) The target should guide both organizational and individual research plans for a given year.

(7) Based on the target the faculty members and research scholars are asked to submit working papers and working books report as per their research topics and the objectives of the research centres they are heading.

(8) The primary targets for research and publications should be supported by secondary targets like organizing conferences periodically to provide a platform to present their papers, to interact with similar objective researchers for collaborations etc. This also includes setting the target to participate in a minimum number of conferences, research workshops/seminars, and faculty development programmes which enhance their knowledge, confidence, and creates new ideas for research and publications. (9) Finally, the documented target should be published on the website of the organization under working paper series so that there will a constant pressure on each and every researcher to fulfill the promise in the form of announced target.

\section{Motivation :}

Once the target for optimum research and publication is set, the organizational leaders should develop and implement various policies to support researchers to meet the targets. Motivation may include support to identify research problems, providing financial support for research expenditures, appreciation of good performers, providing library and internet facility for extended hours, encouragement for collaborative research, publication support, developing research based curriculum, patent support, both financial and career advancement support for better performer etc. The various steps to be followed in Motivation of researchers are :

(1) Creating interest in research and publications by higher authorities.

(2) Giving importance to individual ideas for group based research and involving every member of the group in discussions, research and publications.

(3) This group process also helps members discover their potential through selfexploration.

(4) The researchers also influenced by their reference group namely ideal performers.

(5) As a result of this ideas become translated into performance.

(6) Motivation is a fundamental factor to engage the researchers in quality research and publications through tangible and intangible encouragement.

\section{Work Strategies :}

The strategy is important for success. First and foremost, it is important that the research members of the organizations set their individual goals in consonance with the organizational goal. This comes in the form of a desire. A time-frame plan is essential for 
individuals and groups to accomplish their target. Working on different research projects simultaneously will give relaxation for researchers instead of continuously working in a single project continuously. Writing books on completed and published series of research papers is one of the strategies in enhancing research performance. Collaborating with many people and with many organizations and working on a number of projects and papers simultaneously is another strategy. Writing review papers and developing case studies wherever appropriate is the third strategy in achieving the targets. The various steps to be followed in forming Work Strategies are :

(1) Planning time-oriented research and publications by developing working papers.

(2) Assuming a competitive environment in individual and team progress in research publication performance.

(3) Monitoring the progress by themselves periodically and taking corrective measures periodically.

(4) Feeling enjoyment and satisfaction through the fulfillment of individual and group target achievements.

(5) Re-defining the target based on successive fulfillment

(6) Finally getting organizational support to fulfill the target as an enabling strategy.

\section{Responsibility :}

This is the major component of both individual and organizational success. When the researchers show their responsibility towards fulfilling the organizational objective which is enhancing the research productivity through improved publications, no other influencing factors are required for the better performance by groups and individuals. But based on personality type, only a few people take responsibility by themselves in any organization. For others, an external stimulus is required to point out their responsibilities. Such stimuli may be setting the target, motivation, continuous follow-up, showcasing role model or encouragement.

The various characteristics of responsibilities within the researchers are :

(1) Assuming responsibility is owing responsibility, rather the manifestation of commitment.

(2) Responsibility gives speed and certainty of actions in delivering the goal.
(3) Responsibility inspires task execution which is a crucial part of all in meeting the target.

(4) Responsibility leads to goal attainment that helps target fulfillment.

\section{Role model :}

Super researchers can be the inspiration for every researcher in higher education institutions. By appreciating and showcasing their research output, organizations can set a higher target for all researchers. Role models can be anybody in the organization who outperform in research and contribute highest research output for the organization. Irrespective of age, gender, position and any kind of administrative responsibilities, role models can inspire every researcher in the organization and prove that higher research productivity is possible irrespective of any organizational and individual constraints.

The various steps to be followed in developing and showcasing Role Model are :

(1) Superior performance is highlighted and spread to everybody in the organization.

(2) Best research performers become role models in higher educational institutions which influence other members in their performance.

(3) This results in a change of attitude of researchers (both faculty members and students) from somewhat positive to highly positive and from mediocre performance ro high performance.

(4) Develops an intuition and inner motivation to perform like role models.

\section{Monitoring :}

Continuously monitoring the research and publication progress and accelerating the research and publication productivity is essential to the leaders like research guides, group leaders, head of the departments, director etc. of the higher educational institution. This will automatically create responsibility and avoids procrastination nature of the faculty members and research students. The process of monitoring the research and publication progress include both self-monitoring and monitored by superiors. Monitoring can be done by the superiors on progress of research and publication by means of conducting weekly meetings, periodic faculty presentations and giving deadlines 
through institutional conferences or inviting papers for special issues of institutional journals.

The various steps to be followed in continuous Monitoring are :

(1) There would be periodic re-visits to the targets set, its execution, and lag if any.

(2) This gives an opportunity for every researcher to appraise their contribution.

(3) As a consequence, the timeframe is set for the lag to regain productivity.

(4) Such continuous monitoring, accompanied guidance and suggestions lead the members to accomplish the task.

\section{Accountability :}

Based on objectives of higher educational institutions, at the time of recruitment, the research-oriented faculty members should be given preference. While fixing the workload for faculty members, equal importance should be given to both teaching and researching. As a result, the higher education institution will rightly fix the target to each and every faculty. Similarly while designing curriculum for higher education courses, the institution should give special focus on a research-based curriculum where one or two papers should be added based on research and publications so that research atmosphere can be created among everybody in the organization. Performancebased incentives for the faculty researchers and publication based grades for the students will add accountability for both faculty researchers and student researchers. Research and publication accountability should be fixed to everybody including the heads of the departments and director of the organization so that satisfactory justice can be maintained throughout the organization. Depending on the organizational policy, the accountability may be positive or negative for achievers or losers respectively.

The various methods to be followed in fixing accountability in higher educational institutions are :

(1) Individual commitment and performance are evaluated based on their research productivity periodically during performance assessment. Performance is measured against group goal, individual goal while setting the target, and while providing the organizational support.
(2) During the assessment, the annual research index can be calculated to measure the performance using $\mathrm{ABC}$ model.

(3) Acknowledgment of contribution is shared between individual and organization. High performers will be rewarded positively and poor performers will be rewarded negatively to maintain accountability of individuals and groups in the institution.

\section{INTERCONNECTING THEORY A \& ABC MODEL :}

As per theory A, the research institution should have confined objective on research contribution by using resources in the institution. Based on the research objectives developed in the board meeting, the director has a responsibility of implementing the research objectives by fixing the goal of researchers and allocating the resources as per the requirement. The institutional director has a great responsibility of managing and directing the researchers by setting their target as per the institutional objectives. Accordingly, individual researcher (both faculty members and students) should plan their research and identify their working papers. Based on such plan and presentation of such plan in organizational meetings, the director can set the individual and collective target for every year. The next stage of theory $A$ is the motivation of researchers by encouraging them to work hard and continuous follow-up in the research activities. In this stage, the individual and the departmental work strategies should be studied and supported. By arranging conferences and meetings with experts, the researcher's morale and confidence on thinking innovatively can be boosted. The institution should have policies to promote research and publications by providing support services to the researchers so that there should not be any constraints to the researchers to publish their work. Based on theory A, there should be stated policy annually to publish papers in journals (A), publish books on subjects (B), and the case studies and book chapters $(\mathrm{C})$ so that institution can plan for high annual research index. The institution should share the responsibility to each and every researcher to fulfill the objective of reaching the planned research index. In this responsibility, the director and some senior professors should act 
as role model for young researchers by showing their super-researcher ability. The director of the institution has a dual role as super-researcher role-model and as a superguide by monitoring everybody's progress and supporting them to reach their goal. This can be achieved by arranging faculty/researchers meeting every week to follow-up the progress. Based on such continuous monitoring, by the director of the organization, the institution can achieve its goal of improving research performance. Finally, the review on research performance and publications of all the researchers/faculty members should be carried out including director of the institution based on stated metric to calculate individual annual research index and institutional annual research index. The annual research index of individual faculty can be compared with the standard grading table, as given in table 1 and individual faculty grading can be determined. Depending on the grading level achieved by the faculty members and their contribution to the research, increments and promotion or demotion or relieving from the job should be decided so that each and every faculty including the director will be made accountable for the organizational research performance according to 'Theory A'. To support the role model construct factor of theory A, which inspires the performance of employees in an organization, we have calculated the average annual weighted research index.

Table 1 : Annual Performance Indicator Chart of individual researcher grade based on expected annual research index [35].

\begin{tabular}{|l|l|l|l|}
\hline S. No. & Annual Research Index & $\begin{array}{l}\text { Annual Weighted } \\
\text { Research Index }\end{array}$ & $\begin{array}{l}\text { Individual Annual/Average } \\
\text { Researcher Grade }\end{array}$ \\
\hline 1 & 24 \& above & 3.0 \& Above & Super Research Performer \\
\hline 2 & $16-24$ & $2.0-3.0$ & Optimum Research Performer \\
\hline 3 & $8-16$ & $1.0-2.0$ & Best Research Performer \\
\hline 4 & $4-8$ & $0.5-1.0$ & Better Research Performer \\
\hline 5 & $3-4$ & $0.375-0.5$ & Good Research Performer \\
\hline 6 & $2-3$ & $0.25-0.375$ & $\begin{array}{l}\text { Satisfactory Research } \\
\text { Performer }\end{array}$ \\
\hline 7 & $1-2$ & $0.125-0.25$ & Poor Research Performer \\
\hline 8 & $0-1$ & $0-0.125$ & Non-Performer \\
\hline
\end{tabular}

Table 2 : Factors connecting Theory A and ABC Model

\begin{tabular}{|l|l|l|l|}
\hline S. No. & Concerned Factor & Theory A & ABC Model \\
\hline 1 & Organization type & $\begin{array}{l}\text { Any business organization which } \\
\text { has profit/performance } \\
\text { motivation. }\end{array}$ & $\begin{array}{l}\text { Higher education \& research } \\
\text { organization with performance } \\
\text { motivation through new } \\
\text { knowledge creation. }\end{array}$ \\
\hline 2 & Objectives & Profit as performance. & $\begin{array}{l}\text { Research output in terms of } \\
\text { publications as Performance. }\end{array}$ \\
\hline 3 & Planning & $\begin{array}{l}\text { Essential stage as organizational } \\
\text { performance planning. }\end{array}$ & $\begin{array}{l}\text { Essential stage as institutional } \\
\text { research performance planning. }\end{array}$ \\
\hline 4 & Target & $\begin{array}{l}\text { Each division and Managers } \\
\text { should have a set target for } \\
\text { production or service delivery. }\end{array}$ & $\begin{array}{l}\text { Each faculty/research scholar } \\
\text { should have set target in the form } \\
\text { of working papers. }\end{array}$ \\
\hline 5 & Motivation & $\begin{array}{l}\text { Essential element in any } \\
\text { organization to achieve the } \\
\text { business goal. }\end{array}$ & $\begin{array}{l}\text { Essential element in any } \\
\text { institution to achieve the research } \\
\text { goal. }\end{array}$ \\
\hline 6 & Work strategies & $\begin{array}{l}\text { Essential element in any } \\
\text { organization to confirm the } \\
\text { progress. }\end{array}$ & $\begin{array}{l}\text { Essential element in any higher } \\
\text { education \& research institution } \\
\text { to confirm the progress. }\end{array}$ \\
\hline 7 & Responsibility & Basic requirement for managers in & Basic requirement for researchers \\
\hline
\end{tabular}




\begin{tabular}{|c|c|c|c|}
\hline & & doing the task. & $\begin{array}{l}\text { in the process of new knowledge } \\
\text { invention. }\end{array}$ \\
\hline 8 & Role model & $\begin{array}{l}\text { Encouragement, motivation, and } \\
\text { confidence building on managers } \\
\text { to outperform by showing Role } \\
\text { models within/ external to the } \\
\text { organization to prove that goal } \\
\text { can be achievable. }\end{array}$ & $\begin{array}{l}\text { Encouragement, motivation and } \\
\text { confidence building on } \\
\text { researchers to outperform by } \\
\text { showing Role models within/ } \\
\text { external to the institutions who } \\
\text { have made super-performance to } \\
\text { prove that the target can be } \\
\text { achievable. }\end{array}$ \\
\hline 9 & Monitoring & $\begin{array}{l}\text { By means of continuous follow- } \\
\text { up, by top level managers, } \\
\text { everybody in the organization } \\
\text { should be made to focus on their } \\
\text { objective with continuous } \\
\text { guidance. }\end{array}$ & $\begin{array}{l}\text { By means of continuous follow- } \\
\text { up, by research guide/Director of } \\
\text { the organization, everybody in } \\
\text { the organization should be made } \\
\text { to focus on their work and } \\
\text { publication through continuous } \\
\text { guidance. }\end{array}$ \\
\hline 10 & Accountability & $\begin{array}{l}\text { The central element which } \\
\text { promotes 'do or die' policy in the } \\
\text { organization. Through incentives } \\
\text { for winners \& actions on losers, } \\
\text { the organization should develop a } \\
\text { strict policy for achieving its } \\
\text { objectives. }\end{array}$ & $\begin{array}{l}\text { The central element which } \\
\text { promotes 'publish or perish' } \\
\text { policy in the higher education or } \\
\text { research institution. Through } \\
\text { incentives/ promotions for } \\
\text { performers \& actions on } \\
\text { nonperformers, the organization } \\
\text { should develop a strict policy for } \\
\text { achieving its objectives. }\end{array}$ \\
\hline
\end{tabular}

Table 2 depicts the interconnection between ABC model of research productivity and organizational theory of accountability. As per the table we can see a close connection between these two concepts. Each and every component of theory A, leads to corresponding support to the proposition of ABC model gives rise to enhanced research productivity. As a result, it can be argued that higher educational institutions which follow and adopt organizational theory for $21^{\text {st }}$ century - Theory of Accountability can get assured success in enhancing organizational research productivity [55].

\section{CONCLUSION :}

By interconnecting Theory A and ABC model of research productivity, organizations can boost their annual research index and outperform in research contribution. As per $\mathrm{ABC}$ model, the annual research performance can be determined by knowing the research index of the institution and is calculated by considering the total number of research publications during that period. Theory A plays an important role in all stages of organizational performance. Adopting Theory A by intensifying all its constructs on organizations dynamic resources namely people, enhance research productivity. This is a management strategy which believes in delivering target as responsibility, feeling of creativity and contribution for motivation, identifying with the organization as commitment and accountability as a hallmark of efficiency. In this paper, we have discussed how Theory A on organization performance can be used for enhancing institutional research productivity. Theory A supports organizations not only to boost their business productivity, but it also guides the strategic procedures to be followed by the higher educational institutions to enhance their research performance as organizational output.

\section{REFERENCES :}

[1] Srinivas Rao, A., Suresh Kumar, P. M., \& Aithal, P. S. (2015). Strategic Planning in Higher Education Institutions : A Case Study of SIMS - VISION 2025. International Journal of Educational 
Science and Research, 5(2), 29-42. DOI: http://doi.org/10.5281/zenodo.61589.

[2] Aithal, P. S., Srinivas Rao, A., \& Suresh Kumar, P. M. (2015). How Innovations and Best Practices can Transform Higher Education Institutions: A case study of SIMS. International Journal of Management (IJM), 6(2), 83 - 98. DOI: http://doi.org/10.5281/zenodo.61594.

[3] Aithal, P. S. (2015). Internal Quality Assurance Cell and its Contribution to Quality Improvement in Higher Education Institutions: A Case of SIMS, GE International Journal of Management Research (IJMR), 3(5), 70-83. DOI: http://doi.org/10.5281/zenodo.266808.

[4] Aithal, P. S., \& Suresh Kumar P. M. (2015). Enhancement of Graduate attributes in Higher Education Institutions through Stage Models. IMPACT: International Journal of Research in Business Management, 3(3), 121 - 130. DOI: $\quad$ http://doi.org/10.5281/zenodo. 61640.

[5] Aithal, P. S., Srinivas Rao, A., \& Suresh Kumar, P. M., (2015). Quality Enhancement in Higher Education Institutions : A case study of SIMS. International Journal of Multidisciplinary Research and Development, 2(5), 18-31. DOI: http://doi.org/10.5281/zenodo.266 940.

[6] Aithal, P. S., (2015). How an Effective Leadership and Governance Supports to Achieve Institutional Vision, Mission, and Objectives. International Journal of Multidisciplinary Research and Development, 2(5), 154-161. DOI: http://doi.org/10.5281/zenodo.266788.

[7] Aithal, P. S., (2015). Strategy Development and Deployment in Higher Education Institutions. Elixir International Journal, 84, 33594 - 33597. DOI: http://doi.org/10.5281/zenodo.266 779 .

[8] Aithal, P. S., (2015). Faculty Empowerment Strategies in Higher Education Institutions. International Journal of Management, IT and
Engineering (IJMIE), 5(7), 108-115. DOI: http://doi.org/10.5281/zenodo.266967.

[9] Aithal, P. S. (2015). MBA++ as a Unique \& Successful Model in Integrated Development of Business Executives. International Journal of Management, IT and Engineering (IJMIE), 5(7), 124-133. DOI: http://doi.org/10.5281/zenodo.266 987.

[10] Aithal, P. S. (2015). Strategies to be adopted in Higher Education Institutions to Enhance Admission Demand. International Journal of Extensive Research, 5, 9-25. DOI: http://doi.org/10.5281/zenodo.268530.

[11] Aithal, P. S. and Sridhar Acharya, P. (2015). Techniques for Electric Energy Auditing in Education System. International Journal of Management, IT and Engineering (IJMIE), 5(7), 318-325. DOI : http://doi.org/ 10.5281/zenodo.2 68544.

[12] Aithal, P. S., Suresh Kumar, P. M. and Deekshitha (2015). Societal Expectation and Institutional Accountability In Higher Education.International Journal of Management, IT and Engineering (IJMIE), 5(7), 361-373. DOI : http://doi.org/10.5281/zenodo.267021.

[13] Aithal, P. S., Suresh Kumar, P. M. \& Pavithra Kumari, (2015). Methods and Approaches for Employability Skill Generation in Higher Educational Institutions. International Journal of Management, IT and Engineering (IJMIE), 5(7), 390-410. DOI: http://doi.org/10.5281/zenodo.267044.

[14] Aithal, P. S. and Harischandra, P., (2015). Quality Enhancement in Higher Education Institutions through Best Practices in Library: A Case of SIMS. International Journal of Management, IT and Engineering (IJMIE), 5(7), 489-505. DOI: $\quad$ http://doi.org/10.5281/zenodo.26 8518.

[15] Reshma, Shailashree, V. T, Sridhar Acharya, P., and Aithal, P. S., (2015). Analysis of Academic Administrative System Implemented at SIMS. International Journal of Management, IT 
and Engineering (IJMIE), 5(7), 771-787. DOI : http://doi.org/10.5281/zenodo.267 777.

[16] Pradeep, M.D, and Aithal, P. S., (2015). Learning through Team Centric Exercise \& Key Point Pedagogy - An effective Learning Model for Slow Learners in Higher Education Training. International Journal of Multidisciplinary Research \& Development, 2(9), 265-270. DOI: http: //doi.org /10.5281/zeno do.26 7765.

[17] Aithal, P. S. \& Suresh Kumar, P. M., (2016). Opportunities and Challenges for Private Universities in India. International Journal of Management, IT and Engineering (IJMIE), 6 (1), 88-113. DOI : http://doi.org/10.5281/zenodo.161157.

[18] Aithal, P. S., \& Suresh Kumar P.M., (2016). Innovations in Private Universities: A Case of Srinivas University, International Journal of Management, IT and Engineering (IJMIE), 6(1), 250-264. DOI : http://doi.org/10.5281/zenodo.161151.

[19] Aithal, P. S., (2016). Creating Innovators through setting up organizational Vision, Mission and Core Values : a Strategic Model in Higher Education, International Journal of Management, IT and Engineering (IJMIE), 6(1), 310-324. DOI : http://doi.org/10.5281/zenodo.161147.

[20] Aithal, P. S. \& Shubhrajyotsna Aithal, (2016). Impact of On-line Education on Higher Education System. International Journal of Engineering Research and Modern Education (IJERME), 1(1), 225235. DOI : http://doi.org/10.5281/zeno do.161113.

[21] Sridhar Acharya, P. and Aithal, P. S., (2016). Environmental Consciousness in Higher Educational Institutions : A case of SIMS, International Journal of Current Research and Modern Education (IJCRME), 1(1), 273-284. DOI : http://doi.org/10.5281/zenodo.161083.

[22] Aithal, P. S., and Suresh Kumar, P.M., (2016). Analysis of Choice Based Credit System in Higher Education. International Journal of Engineering Research and Modern Education
(IJERME),1(1), 278-284. DOI : http://doi.org/10.5281/zenodo.161046.

[23] Aithal, P. S., and Suresh Kumar, P. M., (2016). Teaching - Learning Process in Higher Education Institutions. International Journal of Multidisciplinary Research and Modern Education (IJMRME), 2(1), 662-676. DOI : http://doi.org/10.5281/zenodo.160956.

[24] Aithal, P. S., and Suresh Kumar, P. M., (2016). Student performance and Learning Outcomes in Higher Education Institutions. International Journal of Scientific Research and Modern Education (IJSRME), 1(1), 674 - 684. DOI : http://doi.org/10.5281/zenodo. 160944.

[25] McGregor, D. M. (1960). The human side of enterprise. New York: McGraw-Hill.

[26] Ouchi, W. G., \& Price, R. L., (1978). Hierarchies, clans and theory Z: A new perspective on organization development. Organizational Dynamics, 7(2), 25-44.

[27] Aithal, P. S., \& Suresh Kumar, P. M. (2016). Organizational Behaviour in $21^{\text {st }}$ Century - Theory A for Managing People for Performance. IOSR Journal of Business and Management (IOSR-JBM), 18(7), 126-134. DOI: 10.9790/487X180704126134.

[28] Aithal, P. S. (2016). How to Increase Research Productivity in Higher Educational Institutions -SIMS Model. International Journal of Scientific Research and Modern Education (IJSRME), 1(1), 447-458. DOI : http://doi.org/10.5281/zenodo.161037.

[29] Aithal, P. S., \& Suresh Kumar, P. M. (2016). Comparative Analysis of Theory $\mathrm{X}$, Theory Y, Theory Z, and Theory A for Managing People and Performance. International Journal of Scientific Research and Modern Education (IJSRME), I(1), 803-812. DOI: http://doi.org/10.5281/zenodo.154600.

[30] Aithal, P. S. \& Suresh Kumar, P. M. (2016). Theory A for Optimizing Human Productivity, IRA-International Journal of Management \& Social Sciences, 4(3), 
526-535. DOI : http://dx.doi.org/10.2 1013/jmss. v4.n3.p2.

[31] Aithal, P. S. \& Suresh Kumar, P. M. (2016). CCE Approach through ABCD Analysis of 'Theory A' on Organizational Performance. International Journal of Current Research and Modern Education (IJCRME), 1(2), 169-185. DOI: http://dx.doi.org/10.52 81/ zenodo. 164704.

[32] Aithal, P. S. \& Suresh Kumar, P.M., (2016). ABC Model of Research Productivity and Higher Educational Institutional Ranking, International Journal of Education and Management Engineering (IJEME), 6(6), 74-84. DOI: 10.5815/ijeme.2016.06.08.

[33] Aithal, P. S. (2016). Study of Annual Research Productivity in Indian Top Business Schools. International Journal of Scientific Research and Modern Education (IJSRME), 1(1), 402-414. DOI : http://doi.org/10.5281/zenodo.161041.

[34] Aithal, P. S. (2016). Study of Research Productivity in World Top Business Schools, International Journal of Engineering Research and Modern Education (IJERME), 1(1), 629-644, DOI : http://doi.org/10.5281/zenodo.160969.

[35] Aithal, P. S., Shailashree V. T\& Suresh Kumar P. M., (2016). Analysis of ABC Model of Annual Research Productivity using ABCD Framework. International Journal of Current Research and Modern Education (IJCRME), 1(1), 846-858. DOI : http://doi.org/10.5281/zenodo.62022.

[36] Aithal, P. S. (2016). Research Performance Analysis of Some Indian Top Business Schools Using ABC Model. International Journal of Computational Research and Development, 1(1), 70-83. DOI :http://doi.org/10.5281/zenodo.1 63532.

[37] Aithal, P. S., (2016). Inspiring through Self-Contribution - An Analysis of How Active the Indian Top Business School Directors in Research \& Publications. International Journal of Engineering Research and Modern Education
(IJERME),1(2), $137 \quad$ - 154. DOI: http://dx.doi.org/10.5281/ zenodo.164690.

[38] Aithal, P. S., (2016). Excellence in Individual Research \& Publications : Examining the Active Role of Role models (Deans) of World Top Business Schools. International Journal of Engineering Research and Modern Education (IJERME), 1(2), 179-199. DOI: http://dx.doi.org/10.5281/ zenodo.1 92881.

[39] Aithal, P. S. \& Suresh Kumar P. M., (2016). ABC Model of Research Productivity and Higher Educational Institutional Ranking, Proceedings of National conference on Curriculum Design and Development for Student centric Learning, pages 11-22, ISBN 97881-929306-9-5.

[40] Rogers, E.M., (1995). Diffusion of Innovation, The Free Press, NY.

[41] Aithal, P. S., \& Varambally, K .V. M. (2006). Security Issues in Online Financial Transactions with Special Reference to Banking Industry. Quality in Service Sector and Managerial Challenges - Allied Publisher Pvt. Ltd., 103-114, ISBN:81-7764-992-2,.

[42] Varambally, K. V. M., \& Aithal, P. S. (2009). Technological Management and Mobile Business Services in India - A Futuristic Approach, Proceedings on MIDISA - SAARC Conference on Change and Continuity : Management Prospects and Challenges, RIM, Thimphu, Bhutan, 121-139.

[43] Varambally, K. V. M., \& Aithal, P. S. (2009). Mobile Business Technology and Business Proliferation of Banks - A futuristic Approach, Amity Business Review - an Indian Journal, 10(1), 9 25.

[44] Aithal, P. S., \& Shubhrajyotsna Aithal, (2015). Ideal Technology Concept \& its Realization Opportunity using Nanotechnology. International Journal of Application or Innovation in Engineering \& Management (IJAIEM), 4(2), 153 -164. DOI: $\quad$ http://doi.org/10.5281/zenodo.61 591. 
[45] Aithal, P. S., \& Shubhrajyotsna Aithal, (2015). Managing Anticipated Breakthrough Technologies of 21st Century - A Review. International Journal of Research \& Development in Technology and Management Sciences, 21(6), 112-133. DOI : http://doi.org/10.5281/zenodo.61617.

[46] Aithal, P. S. (2015). Concept of Ideal Business \& Its Realization using EBusiness Model. International Journal of Science and Research (IJSR), 4(3), 12671274. DOI : http://doi.org/10.5281/zen odo.61648.

[47] Aithal, P. S., \& Shubhrajyotsna Aithal. (2015). An Innovative Education Model to realize Ideal Education System. International Journal of Scientific Research and Management (IJSRM), 3(3), 2464-2469. DOI: http://doi.org/10.5281/zenodo.61654.

[48] Reshma, Aithal, P. S., Shailashree, V. T., \& Sridhar Acharya, P. (2015). An Empirical study on working from home A popular E-business model. International Journal of Advance and Innovative Research, 2(2), 12-18. DOI :http://doi.org/10.5281/zenodo.164429.

[49] Reshma, Aithal, P. S., \& Sridhar Acharya, P. (2015). Relevance of On-line Office Administration through Working from Home in Future Education System, International Journal of Application or Innovation in Engineering \& Management, 4(4), 44-53. DOI : http://doi.org/10.5281/zenodo.163882.

[50] Aithal, P. S., \& Suresh Kumar, P. M., (2015). Applying SWOC Analysis to an Institution of Higher Education. International Journal of Management, IT and Engineering (IJMIE), 5(7), 231-247. DOI : http://doi.org/ 10.5281/zenodo.16 3425.

[51] Aithal, P.S., \& Suresh Kumar, P.M. (2015). Black Ocean Strategy - A Probe into a New type of Strategy used for Organizational Success, GE International Journal of Management Research, 3(8), 45-65. DOI : http://doi.org/10.5281/zeno do.163423.
[52] Aithal, P. S., Shailashree, V. T., \& Suresh Kumar, P. M., (2015). Application of ABCD Analysis Model for Black Ocean Strategy. International Journal of Applied Research (IJAR), 1(10), 331-337. DOI : http://doi.org/10.5281/zenodo.163424.

[53] Aithal, P. S., Shailashree, V. T., \& Suresh Kumar, P. M. (2016). ABCD analysis of Stage Model in Higher Education. International Journal of Management, IT and Engineering (IJMIE), 6(1), 11-24. DOI : http://doi.org/10.5281/zenodo. 154233.

[54] Aithal, P. S. (2016). Study on ABCD Analysis Technique for Business Models, Business strategies, Operating Concepts \& Business Systems. International Journal in Management and Social Science, 4(1), 98-115. DOI : http://doi.org/10.5281/zenodo.161137.

[55] Aithal, P. S. \& Suresh Kumar, P. M. (2016). Application of Theory A on ABC Model to enhance Organizational Research Productivity in Higher Education. International Journal of Advanced Trends in Engineering and Technology (IJATET), 1(1), 142-150. DOI :http://doi.org/10.5281/zenodo.24064. 
